\title{
Student Perceptions of Effective College Teachers
}

\author{
C. Daniel Prather \\ Middle Tennessee State University
}

\begin{abstract}
Being an effective college teacher is typically a major goal of all faculty, especially junior faculty on the tenure-track. As a new tenure-track faculty member interested in improving his teaching skills (and student ratings), the author surveyed aerospace students at Middle Tennessee State University over a three-year period to gain insight into what students consider to be an effective college teacher. The author's findings reveal that students prefer fun and interesting classes where material is clearly explained and reviews and study guides are provided to help students better prepare for tests. Students also most benefit from courses taught by motivated and passionate professors who make the class fun and interesting by incorporating a great deal of hands-on activities and group discussion. Further, they dislike a boring/monotone professor who lectures the entire class period and is unable to clearly explain the material. Finally, students value professors who are passionate and have a sincere desire to teach, show real respect/caring for students, and are knowledgeable of the subject they are teaching.

\section{INTRODUCTION}

“There is no single 'best way' to teach” (Bain, 2004, p. 175).

As a relative newcomer to academia (beginning his fourth year), the author has been very interested in improving his abilities as an educator. Texts with titles such as, "Teaching First-Year College Students” (Erickson, Peters, \& Strommer, 2006) were in large part, his guiding light during these early years. During this same time, however, the author was introduced to student evaluations. In essence, he was told, the students in his classes would evaluate his teaching effectiveness (in addition to possible peer evaluations). It became apparent that these student evaluations would need to be included in his Tenure and Promotion portfolio and would be relied upon to a great extent in measuring his teaching effectiveness. This concerned the author, as he had no idea how effective a teacher he was, nor how to improve upon his teaching. Thus, he began a three-year research effort to obtain information to supplement the formal student evaluations conducted in his classes and to improve upon his teaching.

\section{REVIEW OF LITERATURE}

The author's research on this topic uncovered numerous texts focusing on effective

teaching and effective student learning (Bain, 2004; Berk, 2002; Brookfield, 1990; Davis, 2009; Haile, Lang, 2008; McKeachie \& Svinicki, 2006; Nilson, 2003; Timpson, Burgoyne, Jones, \& Jones, 1997). The majority of these texts focus on effective teaching and/or effective student learning with an emphasis on what the professor should do, become, or include in their courses to reach students and enable these students to not only learn the material, but to enjoy the process and become lifelong learners as a result. Of particular value in not only improving his teaching, but also understanding students and their needs, is the text entitled "McKeachie's Teaching Tips," by McKeachie and Svinicki (2006). Currently in the $12^{\text {th }}$ edition and with a number of chapters contributed by experienced educators, this book contains guidance on topics such as course preparation, making lectures more effective, assessing and evaluating, motivating students, incorporating technology in the classroom, and teaching large classes. As McKeachie (2006) points out in the introduction, however, "There is no one best way of teaching. If you are to continue to develop as a teacher, you will need well-practiced skills, but you also need fresh thinking about why some things worked or didn't work in your last class" (p. xviii). His book indeed provides that "fresh thinking" on this topic.
\end{abstract}


Additionally, there is a wealth of articles on the subject of effective teaching. Particularly helpful to the author were a series of articles by Rebecca Brent and Richard Felder, most of which appeared in Chemical Engineering Education. In one such article, entitled "Things I Wish They had Told Me,” (Felder, 1994), the author endeavored to guide new faculty and prevent many of the typical mistakes made during the first few critical years. Regarding teaching, the author suggests finding a teaching mentor to work closely with. Additionally, he suggests:

o When teaching a class, give students something active to do at least every 20 minutes.

o Learn to identify students in your classes and greet them by name when you see them in the hall.

o Grade tough on homework, easier on time-bound tests.

As a new junior faculty member, the author reasoned that effective teaching would lead to effective student learning. Interestingly, he was introduced to a text on this very subject during the new faculty orientation held at Middle Tennessee State University (MTSU) in fall 2006. The text, authored by Ken Bain (2004), was appropriately titled, "What the Best College Teachers Do." Dr. Bain is currently Vice Provost for Instruction and Director of the Research Academy for University Learning at Montclair State University. He has been the founding director of four major teaching and learning centers: the Center for Teaching Excellence at New York University, the Searle Center for Teaching Excellence at Northwestern University, the Center for Teaching at Vanderbilt University, and the Research Academy for University Learning at Montclair State University.

His book details the findings of a 15-year study of 100 collegiate educators defined as the "best." "All had achieved," he explains, "remarkable success in helping their students learn in ways that made a sustained, substantial, and positive influence on how those students think, act, and feel” (Bain, 2004, p. 5). Although the study involved countless hours of observations, conversations, examination of course syllabi, assessments, and samples of student work, the research team also acquired data from students, insisting on "evidence that most of their students were highly satisfied with teaching and inspired ... to continue to learn" (p. 7). As Bain (2004) notes, "if students emerged from the class hating the experience, they were less likely to continue learning, or even retain what they had supposedly gained from the class” (p. 7). His study concluded that:

o Without exception, outstanding teachers know their subjects extremely well. They are all active and accomplished scholars, artists, or scientists (p. 15).

o Exceptional teachers treat their lectures, discussion questions, problem-based sessions, and other elements of teaching as serious intellectual endeavors as intellectually demanding and important as their research and scholarship (p. 17).

o Simply put, the best teachers expect more (p. 18).

o While methods vary, the best teachers often try to create what we have come to call a 'natural critical learning environment.' In that environment, people learn by confronting intriguing, beautiful, or important problems, authentic tasks that will challenge them to grapple with ideas, rethink their assumptions, and examine their mental models of reality. These are challenging yet supportive conditions in which learners feel a sense of control over their education; work collaboratively with others; believe that their work will be considered fairly and honestly; try, fail, and receive feedback from expert learners in advance of and separate from any summative judgment of their effort (p. 18).

o Highly effective teachers tend to reflect a strong trust in students. They usually believe that students want to learn, and they assume, until proven otherwise, that they can (p. 18).

o All the teachers we studied have some systematic program -some more elaborate than others -to assess their own efforts and to make appropriate changes (p. 19). 


\section{METHODOLOGY}

\section{Purpose}

This research effort was designed to elicit student feedback regarding the aspects of a course and the qualities of a professor considered valuable. In essence, the purpose of this research was to gain insight into what students consider to be an effective college teacher. To accomplish this, student responses were sought to the following four research questions:

1. What can I do to help you do your best in this course?

2. Think about a course you've taken in the past that worked really well for you. What was it about the course that made it work?

3. Now think about a course that didn't work so well. What was it about the course that made it work not so well?

4. What do you value in a professor?

\section{Participants}

The potential participants in this longitudinal, qualitative study included all Aerospace students enrolled in one of the author's Junior- or Senior-level Aerospace courses at Middle Tennessee State University during the 2006-2007, 2007-08, and 2008-09 academic years. These courses included Airline Management, Airport Management, Airport Planning \& Design, FBO Management, and Flight Safety. Rather than any of these courses being a "core" course required of all Aerospace students, the majority of those enrolled in these courses were Aerospace Administration (Management) majors, although other Aerospace majors were also represented (such as Dispatch \& Scheduling, Professional Pilot, Maintenance Management, and Technology).

There were a total of 394 students included in the study. However, 29 of these students were in two of the author's classes simultaneously; thus, their responses were only counted once. This resulted in a total 365 unique student responses. It should be noted, however that some student answers bridged across several themes and thus the total number of themes does not equal the total number of unique student responses.

\section{Survey Instrument}

Students were asked to answer the four open-ended questions previously noted on an index card during the first day of class each semester. In addition to answering these questions, students were asked to provide their name, hometown, major/concentration, reason for signing up for the course, number of hours working each week this semester, the extent of aviation industry experience they may have, and what they anticipate might be difficult for them in the course. Providing any of this information was optional for students, although the vast majority chose to respond to all items.

\section{Analysis}

This research effort only collected qualitative data from students. As a result, content analysis was the method used to analyze the data. Specifically, once all responses were input into a Microsoft Word table, the author read each individual response and developed themes (or categories) for these responses. These themes then allowed a comparison of responses in a more organized fashion.

\section{Limitations}

Due to the adoption of a convenience sampling technique, only Junior- and Seniorlevel Aerospace students attending one of the author's Aerospace courses at Middle Tennessee State University from 2006 to 2009 were included in this study. Therefore, no inferences can be drawn from these results to the population of collegiate aviation students nationwide.

\section{RESULTS}

1. What can I do to help you do your best in this course?

\begin{tabular}{|l|c|}
\hline \multicolumn{1}{|c|}{ Theme } & $\begin{array}{c}\text { Number of } \\
\text { Responses }\end{array}$ \\
\hline Clearly explain material & 71 \\
\hline Reviews/Study Guides & 54 \\
\hline Make it fun/interesting & 45 \\
\hline Clear expectations & 37 \\
\hline Relate to real-world & 26 \\
\hline Be available & 25 \\
\hline Use visuals/Powerpoints & 21 \\
\hline $\begin{array}{l}\text { Post/make available } \\
\text { slides/lecture notes }\end{array}$ & 12 \\
\hline
\end{tabular}




\begin{tabular}{|l|c|}
\hline \multicolumn{1}{|c|}{ Theme (cont'd) } & $\begin{array}{c}\text { Number of } \\
\text { Responses }\end{array}$ \\
\hline Personable/Encouraging/Flexible & 12 \\
\hline $\begin{array}{l}\text { Hands-on activities/Experiential } \\
\text { learning }\end{array}$ & 11 \\
\hline Ask/Answer questions & 10 \\
\hline Appropriate pace & 9 \\
\hline Help students & 8 \\
\hline Minimal work required & 6 \\
\hline Good grade/able to graduate & 3 \\
\hline Discuss career opportunities & 1 \\
\hline
\end{tabular}

2. Think about a course you've taken in the past that worked really well for you. What was it about the course that made it work?

\begin{tabular}{|l|c|}
\hline \multicolumn{1}{|c|}{ Theme } & $\begin{array}{c}\text { Number of } \\
\text { Responses }\end{array}$ \\
\hline Fun/interesting & 52 \\
\hline $\begin{array}{l}\text { Hands-on activities/exp } \\
\text { learning/discussion/groups }\end{array}$ & 49 \\
\hline $\begin{array}{l}\text { Motivated/energetic/passionate/ } \\
\text { humorous professor }\end{array}$ & 44 \\
\hline Reviews/study guides & 29 \\
\hline $\begin{array}{l}\text { Practical application/relate to } \\
\text { real-world/experience }\end{array}$ & 28 \\
\hline Visuals/Powerpoints & 19 \\
\hline Clear expectations & 17 \\
\hline Clearly explained material & 16 \\
\hline Laid-back professor & 14 \\
\hline Student enjoyed subject & 13 \\
\hline $\begin{array}{l}\text { Organized/knowledgeable/well- } \\
\text { prepared professor }\end{array}$ & 13 \\
\hline $\begin{array}{l}\text { Minimal work required/low } \\
\text { expectations }\end{array}$ & 11 \\
\hline $\begin{array}{l}\text { Slides/Lecture notes posted on- } \\
\text { line/made available }\end{array}$ & 7 \\
\hline Verify class comprehension & 7 \\
\hline Instructor availability & 7 \\
\hline More than just lecture & 6 \\
\hline Help students & 4 \\
\hline Challenged me & 2 \\
\hline Guest speaker & 1 \\
\hline Group exams & \\
\hline
\end{tabular}

3. Now think about a course that didn't work so well. What was it about the course that made it work not so well?

\begin{tabular}{|c|c|}
\hline Theme & $\begin{array}{l}\text { Number of } \\
\text { Responses }\end{array}$ \\
\hline $\begin{array}{l}\text { Boring class/monotone } \\
\text { professor }\end{array}$ & 62 \\
\hline Straight lecture & 50 \\
\hline $\begin{array}{l}\text { Did not clearly explain } \\
\text { material }\end{array}$ & 22 \\
\hline Professor not organized & 18 \\
\hline Too fast-paced & 17 \\
\hline Too many/pointless activities & 16 \\
\hline Poor communicator & 16 \\
\hline No review/study guides & 16 \\
\hline $\begin{array}{l}\text { Professor had no } \\
\text { respect/concern for students }\end{array}$ & 16 \\
\hline $\begin{array}{l}\text { No class } \\
\text { participation/interaction/hands } \\
\text {-on activities }\end{array}$ & 15 \\
\hline Difficult tests & 15 \\
\hline $\begin{array}{l}\text { No clear } \\
\text { objectives/expectations }\end{array}$ & 15 \\
\hline Disliked subject & 12 \\
\hline $\begin{array}{l}\text { Tested on material not covered } \\
\text { in class }\end{array}$ & 12 \\
\hline $\begin{array}{l}\text { Professor not motivated, } \\
\text { doesn't enjoy teaching }\end{array}$ & 12 \\
\hline Too much material & 10 \\
\hline Professor not knowledgeable & 8 \\
\hline Professor was impersonal & 6 \\
\hline Professor was not available & 6 \\
\hline Class was too difficult & 6 \\
\hline $\begin{array}{l}\text { Students had to teach } \\
\text { themselves }\end{array}$ & 5 \\
\hline Group projects & 4 \\
\hline No real-world application & 4 \\
\hline No control over class & 3 \\
\hline Large class & 2 \\
\hline Pop quizzes & 2 \\
\hline On-line class & 2 \\
\hline Didn’t learn much & 1 \\
\hline
\end{tabular}


4. What do you value in a professor?

\begin{tabular}{|l|c|}
\hline \multicolumn{1}{|c|}{ Theme } & $\begin{array}{c}\text { Number of } \\
\text { Responses }\end{array}$ \\
\hline $\begin{array}{l}\text { Sincere desire to } \\
\text { teach/passionate }\end{array}$ & 81 \\
\hline Respect/caring for students & 67 \\
\hline Knowledgeable & 37 \\
\hline Accessibility/Availability & 37 \\
\hline Approachable/Friendly & 35 \\
\hline $\begin{array}{l}\text { Honesty/Integrity/ } \\
\text { Professionalism }\end{array}$ & 34 \\
\hline $\begin{array}{l}\text { Ability to make class } \\
\text { fun/interesting }\end{array}$ & 30 \\
\hline $\begin{array}{l}\text { Flexible/easy going/laid } \\
\text { back }\end{array}$ & 29 \\
\hline Industry experience & 20 \\
\hline $\begin{array}{l}\text { Explains subject matter } \\
\text { clearly }\end{array}$ & 20 \\
\hline Sense of humor & 20 \\
\hline $\begin{array}{l}\text { Ability to communicate } \\
\text { effectively }\end{array}$ & 17 \\
\hline Understanding & 15 \\
\hline Organized & 9 \\
\hline Fair & 5 \\
\hline Confidence & 4 \\
\hline $\begin{array}{l}\text { Challenges students to } \\
\text { higher level }\end{array}$ & 5 \\
\hline
\end{tabular}

\section{DISCUSSION}

By examining the top three themes in each of these four categories, it is possible to gain insight into student perceptions regarding the qualities of an effective (or ineffective) teacher. Clearly, the content analysis (as revealed in each table) reveals themes subscribed to by a large number of students, as well as those themes only subscribed to by small numbers of students. Regardless, all possible themes that could be developed from the responses are listed.

Students were first asked, "What can I do to help you do your best in this course? The vast majority were looking for clearly explained material. If the professor ineffectively explains the course material, students find it difficult to do well in the class. As one student encouraged, "Explain everything." The next most popular theme was providing reviews and/or study guides. These reviews and study guides, students reasoned, will enable them to perform better on tests/exams than if they had no such guidance. As one student shared, "Guide me on the course matter that will be covered on the tests. Surprises are no fun!" The third most popular theme was for the professor to make it fun and/or interesting. The vast majority of students participating in this research effort detest "boring" classes. Indeed, they have a true desire to attend class if the professor makes it fun and interesting. As one student stated, "Just don't bore me to death.” By combining these three most popular themes in one course, it would seem that to most help students, the professor should make every effort to have a fun and interesting class where material is clearly explained and reviews and study guides are provided to students to help them better prepare for tests.

The second question asked students to think about a course that worked really well for them and explain what it was, specifically, about that course that made it work for them. The most popular theme in response to this question was that the course was fun and/or interesting. As one student shared, "The teacher made the class interesting and enjoyable. You wanted to go to class because you didn't want to miss the enjoyment of the teacher's enthusiasm." With many classrooms full of "disengaged, unmotivated, and unchallenged" students, this comment is worthy of consideration (Bliss, 2002, p. 10). Bain (2004) provides insight into why a fun and interesting class is necessary, by explaining that "if students study only because they want to get a good grade or be the best in the class, they do not achieve as much as they do when they learn because they are interested" (p. 33). The next most popular theme was the inclusion of hands-on activities/experiential learning/discussion/groups. This goes hand-inhand with the first response, as these activities typically make a class more fun/interesting. Bliss (2002) refers to this as the "creative context" and explains that "the ideal creative classroom should cultivate the creativity of both the students and the instructor” (p. 11). The third most popular theme in this category was a motivated/energetic/passionate/humorous

professor. Typical student comments included "The professor was funny," The instructor was passionate about the subject," and "The teacher 
was very energetic.” As Bain (2004) explains, "Many students . . . talked about 'something she does' and told us they 'can't explain it,' but that certain teaching inspired their efforts" (p. 121). By combining these three most popular themes in one course, it would seem that the courses that work most well for students are taught by motivated and passionate professors who make the class fun and interesting by incorporating a great deal of hands-on activities and group discussion.

The third question asked students to share their thoughts on a course that did not work well for them. The most popular theme centered around a boring or monotone professor. This does indeed seem to contrast with the energetic and passionate professor that students preferred in response to question two. Further it is supported by Sandel's statement (as cited in Bain, 2004, p. 109) that "Teaching is 'above all' about commanding attention and holding it." The second most popular theme involved a course in which the professor utilized straight lecture. Although the lecture has been the standard way to impart knowledge to students, it is clear that, according to students participating in this research effort, it is not appreciated. And in fact, if that is what characterizes a class, it is likely not going to work well for students, which of course, means that students are not enhancing their knowledge about a topic (and learning outcomes are not being met). As Bain (2004) explains, "The lecture . . . is not used as an encyclopedic coverage of some subject, or as a way to impress students with how much the teacher knows. We found no great teachers who relied solely on lectures” (p. 107). The third most popular theme shared by students involved courses in which material was not clearly explained by the professor. This contrasts with the most popular theme in question one which involves what a professor can do to help a student do their best in a course (clearly explain material). By combining these three most popular themes in one course, it would seem that courses that did not work well for students were those in which a boring/monotone professor lectured the entire class period and was unable to clearly explain the material.

The fourth and final question simply asked of students what they valued in a professor. The most popular theme in this category involved passionate professors with a sincere desire to teach. This response is similar to the third most popular theme in response to question two. As one student shared, "I value professors who love what they do and are more than happy to share their passion with the class." The second most popular theme in this category involved professors who show respect and caring toward students. Quite a few students responded to this question quite simply, with "They care about their students." Bain (2004) discovered this as well, and explained that "the best teachers tended to look for and appreciate the value of each individual student” (p. 72). The third most popular theme in this category focused on knowledgeable professors. One student succinctly responded with, "Subject matter expert." Fortunately for new faculty asked to teach courses for which they may not be subject matter experts, it would appear from these comments that a professor with little knowledge of the subject may fair well as long as they have a sincere desire to teach and a real respect for their students. By combining these three most popular themes in one course, it would seem that students most value professors who are passionate and have a sincere desire to teach, show real respect/caring for students, and are knowledgeable of the subject they are teaching.

\section{RECOMMENDATIONS}

The purpose of this research was to shed light on what makes an effective college teacher. Whereas Bain (2004) mostly examined the practices of highly effective professors, this research focused solely on student perceptions. It must be emphasized, however, that student comments and student ratings should not be considered in isolation. Indeed, as Bain (2004) admits, "A professor could get high marks on all the conventionally right practices yet have little positive influence on student learning." As a result, all junior faculty are encouraged to develop teaching portfolios, obtain peer evaluations from colleagues, and retain evidence of student learning via projects and other evidence, to supplement student ratings.

At the same time, according to Entwistle and Tait (as cited in Bain, 2004, p. 165), 
"Different kinds of learners might give the same experience conflicting ratings. [For example,] "Deep learners said they liked courses that pushed them to explore conceptual meanings and implications, whereas their classmates who were surface learners hated such experiences." Thus, all student comments and ratings should be considered in light of this. In fact, a professor may receive high marks in one course and low marks in another, simply due to the type of student learner in each of these classes and whether the material is conceptual or not.

Based on the findings of this research effort, the following recommendations are offered (with the caveat that the findings of this research effort were obtained using a convenience sample and may not be inferred to collegiate aviation programs nationwide):

o Professors should make every attempt to clearly explain subject matter covered during each class and further, ensure that students comprehend that subject matter.

o Although the goal in collegiate aviation should be student learning and comprehension, rather than satisfactory student grades, students have operated in a grade-centered learning environment for 12-plus years. As a result, students are very concerned about their grades and earning a high GPA. Professors can minimize student anxiety in this regard by reviewing material prior to exams and/or providing study guides.

o Professors should make every attempt to create fun and interesting classes. Students typically characterize classes in these terms which involve hands-on activities, experiential learning, discussion and group work.

o Professors should be passionate not only about their field, but also about teaching college students. Energy needs to be apparent in every class and professors should also lighten-up and use humor in the class to maintain student interest.

o Professors should be knowledgeable about their material and have actual experience in the field if at all possible.

o Professors should exhibit a high-level of caring and respect for students. Students should understand that the professor is concerned about their learning the material and doing well in the course.

o At all costs, professors should avoid straight lecture classes and being known as the "monotone, boring" professor.

\section{CONCLUSION}

In conclusion, there are many qualities of effective college professors, some of which are easier to acquire than others. Clearly, students want to enjoy their educational experience, and professors can play a large part in making this happen. At the same time, junior faculty must remember that (as Bain, 2004 explains) "High ratings from students indicate success only if I am satisfied with the quality of what I'm asking them to do intellectually, and that is reflected not in the ratings but in my syllabus, assignments, and the ways I grade their work. Low ratings, on the other hand, usually tell me I've failed to reach my students” (Bain, 2004, p. 166).

Therefore, while student perceptions provide great insight into qualities of effective college professors, at least in their minds, we as faculty also speak highly of academic rigor and typically know what is best for the students. That being said, faculty should endeavor to challenge individual students in an academically-rich context that maintains student interest and involvement. As Paul Baker stated (in Bain, 2004), "My strongest feeling about teaching is that you must begin with the student. As a teacher you do not begin to teach, thinking of your own ego and what you know ... The moments of the class must belong to the student - not the students, but to the very undivided student. You don't teach a class. You teach a student” (p. 97). 


\section{REFERENCES}

Bain, K. (2004). What the best college teachers do. Cambridge, MA: Harvard University Press.

Berk, R. A. (2002). Humor as an instructional defibrillator. Sterling, VA: Stylus.

Bliss, T. J. (2002). Designing a creative context that fosters student motivation and engagement in learning. Collegiate Aviation Review, 9-16.

Brookfield, S. D. (1990). The skillful teacher. San Francisco: Jossey-Bass.

Davis, B. G. (2009). Tools for teaching ( $2^{\text {nd }}$ ed.). San Franciso: Jossey-Bass.

Erickson, B. L., Peters, C. B., \& Strommer, D. W. (2006). Teaching first-year college students. San Francisco: John Wiley \& Sons.

Felder, R. M. (1994, Spring). Things I wish they had told me. Chemical Engineering Education, 28(2), 108-109.

Haile, J. M. (2005). The way of the teacher. Central, SC: Macatea Productions.

Lang, J. M. (2008). On course: A week-by-week guide to your first semester of college teaching. Cambridge, MA: Harvard University Press.

Nilson, L. B. (2003). Teaching at its best: A research-based resource for college instructors. Bolton, MA: Anker Publishing Company.

Mathew, A. \& Spencer, D. B. (2008). Incorporating cooperative learning activities into traditional aerospace engineering curricula. Journal of Aviation/Aerospace education and research, 17 (3), 2537.

McKeachie, W. J. \& Svinicki, M. (2006). McKeachie's teaching tips: Strategies, research, and theory for college and university teachers. Boston: Houghton Mifflin.

Timpson, W. M., Burgoyne, S., Jones, C. S., \& Jones, W. (1997). Teaching and performing: Ideas for energizing your classes. Madison, WI: Magna Publications. 